\title{
Dina lineata (O.F. Müller, 1774) - an interesting species of leech in astatic reservoirs of the city of Olsztyn and its surroundings
}

\author{
*Ewa Ropelewska, **Aleksander Bielecki, ***Stanislaw Czachorowski, \\ ****Marcin Ropelewski, *Jerzy Dziejowski \\ * Department of Chemistry, Łódzki Square 4, 10-957 Olsztyn, University of Warmia and Mazury in Olsztyn, Poland; \\ e-mail: ewa.ropelewska@uwm.edu.pl \\ ** Department of Zoology, Oczapowskiego 5, 10-718 Olsztyn, University of Warmia and Mazury in Olsztyn, Poland \\ *** Department of Ecology and Environmental Protection, Lódzki Square 3, 10-727 Olsztyn, \\ University of Warmia and Mazury in Olsztyn, Poland \\ **** Department of Human Resource Management, Prawocheńskiego 3, 10-720 Olsztyn, \\ University of Warmia and Mazury in Olsztyn, Poland
}

\begin{abstract}
The aim of the presently study was to provide information about the occurrence of Dina lineata in selected reservoirs of the city of Olsztyn and its surroundings. The material was collected applying the qualitative method. The leeches were found in the overflows of Olsztyn lakes (Skanda Lake and Redykajny Lake) and small astatic midfield reservoir near Samławki.
\end{abstract}

Keywords: Erpobdellidae, occurrence, ephemeral reservoirs, backwaters.

\section{Introduction}

Dina lineata belongs to the Erpobdellidae family (Siddall 2002). It is a Palearctic species that is not found too frequently (Bielecki et al. 2011b). So far, it has been found in Poland, among others, at the Baltic Coast, Pomeranian Lake District, Mazurian Lake District, Wielkopolsko-Kujawska Lowland, Białowieża Forest, Lower Silesia, Trzebnickie Hills, Upper Silesia and Malopolska Upland (Prost 1966; Bogdanowicz et al. 2004; Bielecki et al. 2011a, modified) (Fig. 1).

Figure 1. Distribution of D. lineata in Poland (marked in red) (2 - Baltic Coast, 3 - Pomeranian Lake District, 4 - Mazurian Lake District, 5 - Wielkopolsko-Kujawska Lowland, 7a - Białowieża Forest, 8 - Lower Silesia, 8a - Trzebnickie Hills, 9 - Upper Silesia, 11 - Małopolska Upland) (Prost 1966; Bogdanowicz et al. 2004; Bielecki i in. 2011a, modified)

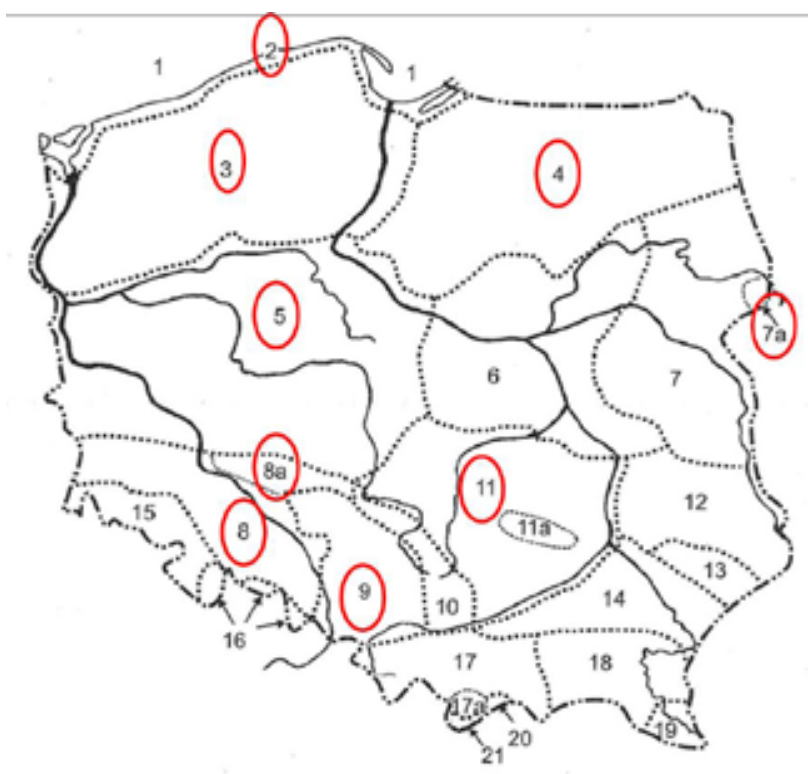


D. lineata prefers astatic and ephemeral reservoirs as its habitat. It is characteristic for clean lentic waters (Bielecki et al. 2011b). Individuals of that species have been collected, among others, from the ponds rich in organic matter and calcium (Mann 1952).

D. lineata is a species included in the Red List IUCN of Endangered Species in Poland (Jażdżewska \& Wiedeńska 2002). It is a predatory species feeding on oligochaetes and larvae of insects (Bielecki et al. 2011a).

The following characteristics can be listed as diagnostic for that species: smooth body with poorly visible papillae, brownish-grey dorsal side of the body, the distance between gonopores is 2.5 annuli, ovaries taking ca. 4 neurosomits, atrium with a large bursa and thick and longs corners (Lukin 1976).

The aim of the study was to collect information on the occurrence of $D$. lineata in the astatic reservoirs situated within the city of Olsztyn and its surroundings.

\section{Study area, material and methods}

The studies were conducted in overflow areas of the lakes situated in the city of Olsztyn: Skanda Lake $\left(53^{\circ} 45^{\prime} 26^{\prime \prime} \mathrm{N}\right.$ $\left.20^{\circ} 31^{\prime} 30^{\prime \prime} \mathrm{E}\right)$ (Fig. 2), Redykajny Lake (5348'55"N $20^{\circ} 25^{\prime} 04^{\prime \prime}$ ) (Fig. 3) as well as the small astatic midfield reservoir situated in the vicinity of Samławki, near Łężany and Reszel (53 $\left.58^{\prime} 00^{\prime \prime} \mathrm{N} 21^{\circ} 08^{\prime} 27^{\prime \prime} \mathrm{E}\right)$ (Fig. 4 and 5). The bottom in the area of Skanda Lake and Redykajny Lake backwaters was sandy and muddy. The analyzed midfield reservoir is a small water reservoir, situated among the arable fields, often ploughed on the banks, drying wholly or partially in the summer. It had clayey bottom and was overgrown by sedge (Carex sp.), rush (Juncus sp.), reedmace (Typha sp.), duckweed (Lemna sp.) and willow shrubs (Salix sp.), however it was located outside the cultivation area of that plant. Both the backwaters of lakes and midfield reservoir were filled with water during the study period (April). At the end of May they began drying up.

The leeches were collected during the fieldwork in the spring 2011 (April 14). It was single a collection of samples in the case of each reservoir. The qualitative method has been applied, which is based on finding a particular species. The species was identified in the way allowing survival of the individuals on the base of morphological characteristics or conducting later analyses at the laboratory. The material was collected from the plant as well as stones and objects situated on the reservoir bottom. The individuals were preserved in $96 \%$ ethanol.

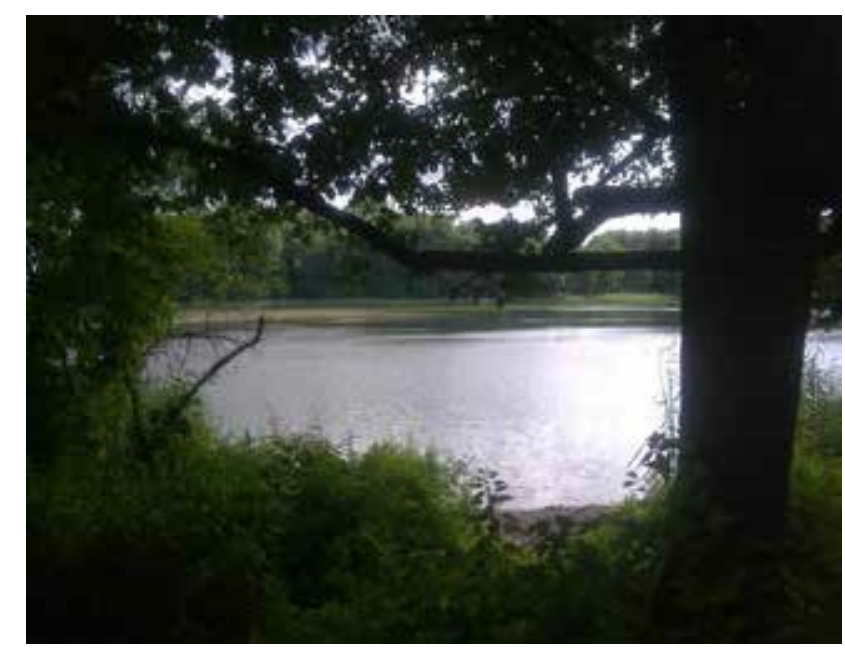

Figure 2. Skanda Lake (Phot. E. Ropelewska)

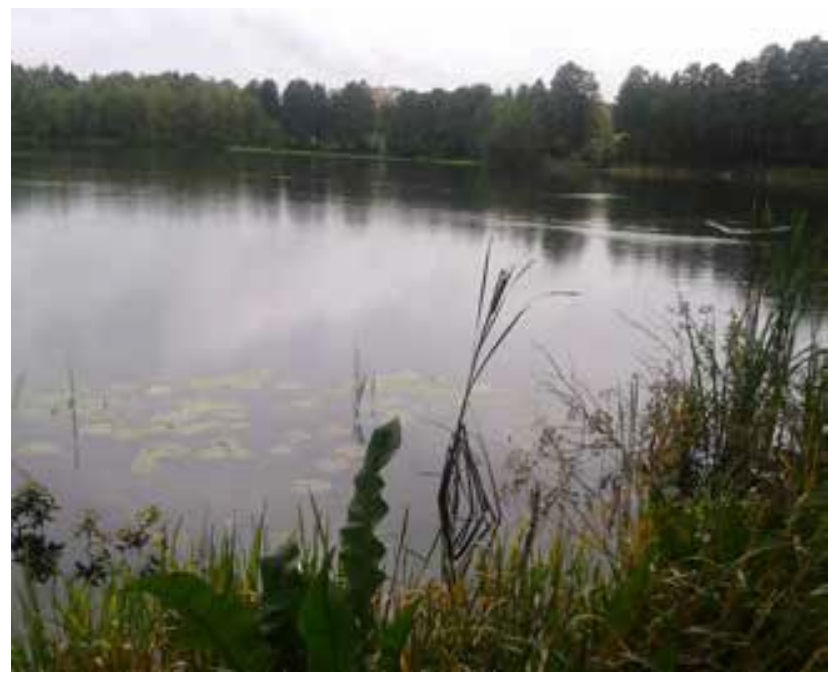

Figure 3. Redykajny Lake (Phot. M. Ropelewski)

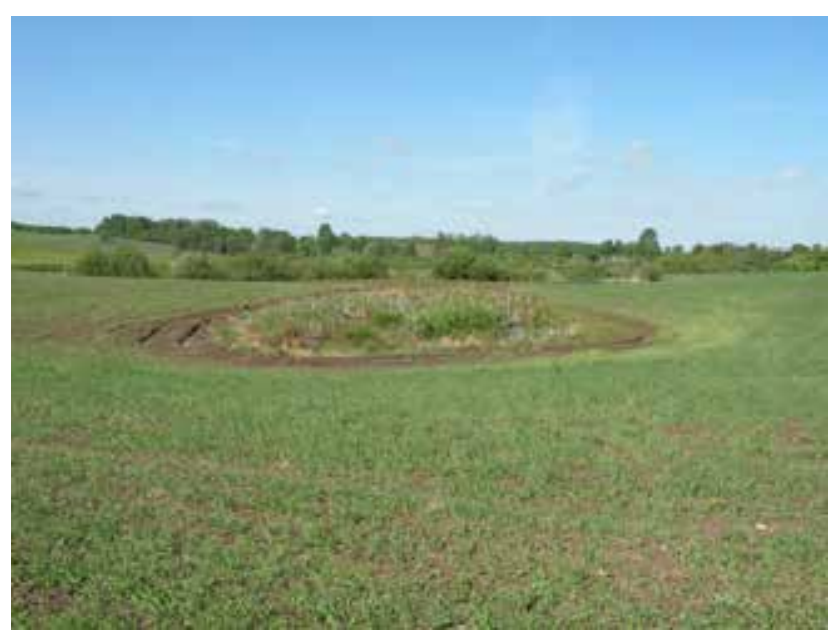

Figure 4. Astatic midfield reservoir situated in the vicinity of Samławki (Phot. S. Czachorowski) 


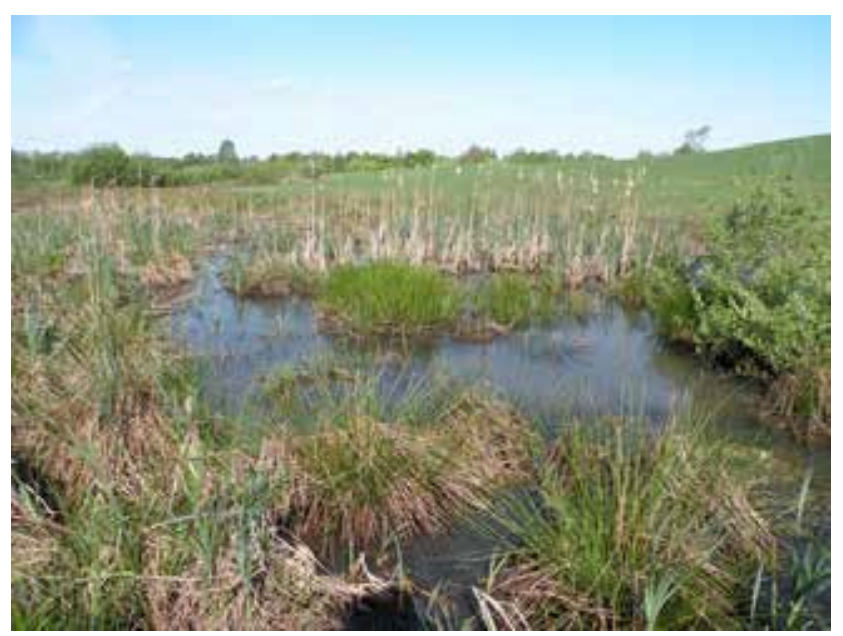

Figure 5. Astatic midfield reservoir situated in the vicinity of Samławki (Phot. S. Czachorowski)

\section{Results and discussion}

During the studies, occurrence of $D$. lineata (Fig. 6) was found in the overflows of Olsztyn lakes and small astatic reservoir. During the studies, occurrence of $D$. lineata was found in the backwaters of Olsztyn lakes and the small astatic reservoir. The literature data confirm the preference of leeches belonging to that species for shallow standing waters with muddy bottom. Zettler and Daunys (2007) reported occurrence of two $D$. lineata individuals in shallow eutrophic lagoons. Bielecki et al. (2011b) describe the discovery of that species in the backwaters of Olsztyn lakes (Skanda Lake and Redykajny Lake). However, Kubová et al. (2013) found one specimen in the lotic reservoir during the studies of $D$. lineata comparing the occurrence of species of leeches in lentic and lotic habitats conducted in the spring (late April - early June). The authors justify this fact by the presence of muddy bottom and low water level. According to the habitat preferences of leeches $D$. lineata, it could be expected that the number of the individuals representing that species would be higher in the small ephemeral reservoir than in the backwaters of lakes. Twelve individuals were found (April 14, 2011) in the backwater of Skanda Lake and 9 individuals (April 14, 2011) in the backwater of Redykajny Lake. A surprisingly large number of leeches belonging to that species were collected from a small astatic midfield reservoir near Łężany. In this place, where the water showed large fluctuations of the level, 28 individuals D. lineata were found (April 14, 2011). In the spring until the beginning of the summer (the end of June), the leeches live in the waters of the reservoir and during the later period, they bury themselves in the clay deposits on the bottom of the drying reservoir. Leeches bury themselves a few centimeters deep. They were not

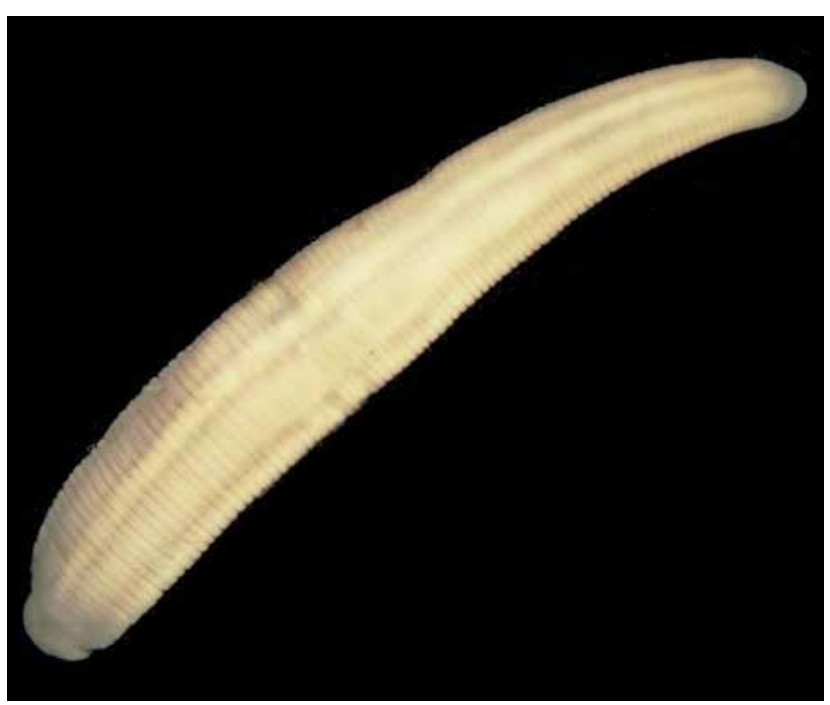

Figure 6. Dina lineata, dorsal view (Phot. A. Bielecki)

collected during that period as special equipment would be needed for mud collection. $D$. lineata can live in water environment at high tolerance to oxygen deficiency (Kalbe 1966). Agapow and Nadobnik (2006) collected individuals of that species in reservoirs with oxygen content of 4.00$4.46 \mathrm{mg} \mathrm{dm}^{-3}$.

$D$. lineata is a very interesting species due to the colonization of specific environments. All the species of genus Dina can live in extreme habitats and it is characteristic for them. Other representatives of this genus may colonize diversified habitats. They may show adaptation to living in the given environment. For example, the change of colour into whitish and disappearance of eyes occurred in Dina absoloni Johansson 1912 living in caves (Sket 1986; Sket et al. 2001). Also, another species of that genus, Dina krasensis, may occur in caves (Sket et al. 2001). Representatives of Dina stschegolewi Lukin et Epstein, 1960 were found in small muddy reservoirs (Lukin \& Epstein 1960) as well as in brackish lakes (Bielecki 1978; Hajduk et al. 1985). While Dina apathyi Gedroyć, 1916 choses water reservoirs as peat ponds, ditches, clay ponds and backwaters for its habitat (Bielecki et al. 2011b). Therefore, knowledge of the biology and ecology of the species belonging to genus Dina, allows assuming during collecting that specimens acquired from a specific habitat belong to a particular species, which is confirmed ultimately by anatomical examinations of the leeches. 


\section{References}

Agapow L. \& Nadobnik J., 2006, Fauna of leeches (Hirudinea) in postglacial tarns in the Dobiegniewskie Lakeland, Teka Komisji Ochrony i Kształtowania Środowiska Przyrodniczego 3: 13-18.

Bielecki A., 1978, Herpobdella (Dina) stschegolewi Lukin et Epstein, 1960 (Hirudinea, Herpobdellidae) - nowy gatunek dla fauny Polski [Herpobdella (Dina) stschegolewi Lukin et Epstein, 1960 (Hirudinea, Herpobdellidae) - the new species for Poland], Przegląd Zoologiczny XXII, 2: 140-143.

Bielecki A., Cichocka J. M., Jeleń I., Świątek P. \& Adamiak-Brud Ż., 2011a, A checklist of leech species from Poland, Wiadomości Parazytologiczne 57(1): 11-20.

Bielecki A., Świątek P., Cichocka J., Ropelewska E., Jeleń I. \& Adamiak-Brud Ż., 2011b, Pijawki (Hirudinida) wód powierzchniowych Olsztyna [Leeches (Hirudinida) of the surface waters in Olsztyn], Forum Faunistyczne 1(1): 12-34.

Bogdanowicz W., Chudzicka E., Pilipiuk I. \& Skibińska E., 2004, Fauna of Poland, Characteristic and checklist of species, Vol. I. Museum and Institute of Zoology, Polish Academy of Sciences, Warsaw.

Hajduk Z., Bielecki A. \& Hajduk D., 1985, Fauna Hirudinea słonawych jezior Modła i Wicko [Fauna of Hirudinea of Modła and Wicko brackish lakes], Acta Universitatis Wratislaviensis, Wrocław, Prace Zoologiczne 599(13): 59-66.

Jażdżewska T. \& Wiedeńska J., 2002, Hirudinea, [in:] Z. Głowaciński (ed.), Red List of Threatened Animals in Poland, Instytut Ochrony Przyrody PAN, Kraków: 144145.
Kalbe L., 1966, Zur Okologie und Saprobiewertung der Hirudinea im Havelgebiet, Internationale Revue der gesamten Hydrobiologie und Hydrographie 51(2): 243277.

Kubová N., Schenková J. \& Horsák M., 2013, Environmental determinants of leech assemblage patterns in lotic and lenitic habitats, Limnologica 43: 516-524.

Lukin E. J. \& Epstein V. M., 1960, Pijavki Baikala, Kh soveshch. po parazitol. probl. i prirod-noochag. bolezhjam 2: 189-190.

Lukin E. J, 1976, Pijawki. Fauna SSSR, Academy of Science of the SSSR, Leningrad.

Mann K. H., 1952, A revision of the British leeches of the family Erpobdellidae, with a description of Dina lineata (O. F. Müller, 1774), a leech new to British fauna, Proceedings of the Zoological Society of London 122(2): 395-406.

Prost M., 1966, Monogenoidea, Katalog Fauny Polski, IV (1): 1-31.

Siddall M. E., 2002, Phylogeny of the leech family Erpobdellidae (Hirudinida: Oligochaeta), Invertebrate Systematics 16: 1-6.

Sket B., 1986, Hirudinea, [in:] L. Botosaneanu (ed.), Stygofauna Mundi, University of Amsterdam, Institute of Taxonomic Zoology, Amsterdam: 250-253.

Sket B., Dovč P., Jalžić B., Kerovec M., Kučinić M. \& Trontelj P., 2001, A cave leech (Hirudinea, Erpobdellidae) from Croatia with unique morphological features, Zoologica Scripta 30: 223-229.

Zettler M. L. \& Daunys D., 2007, Long-term macrozoobenthos changes in a shallow boreal lagoon: Comparison of a recent biodiversity inventory with historical data, Limnologica 37: 170-185. 